\title{
EFFECT OF NONSURGICAL PERIODONTAL THERAPY ON SYSTEMIC PRO-INFLAMMATORY AND VASCULAR ENDOTHELIAL BIOMARKERS AND SERUM LIPID PROFILE IN CHRONIC PERIODONTITIS PATIENTS
}

\author{
Samah H. Elmeadawy*, Hesham M. El-Sharkawy ${ }^{*}$ and Azza Elbayomy**
}

\begin{abstract}
The present study aimed to estimate the serum levels of vascular cell adhesion molecule1(VCAM-1), interleukin-6 (IL-6), and lipid profile [including total cholesterol, triglycerides (TGs), high -density lipoprotein cholesterol (HDL) and low -density lipoprotein cholesterol (LDL)] in chronic periodontitis patients and to detect the association between the aforementioned cardiovascular disease risk markers and the periodontal disease severity and extent. In addition, the study also aimed to detect whether the non-surgical periodontal treatment (NSPT) may affect the levels of these biochemical parameters. Fifty eight subjects completed the study and were subdivided into: group I (31 chronic periodontitis patients), and group II (27 adults with clinically healthy gingivae). Group I received standard NSPT. Periodontal parameters and serum levels of VCAM-1, IL-6, and lipid profile were estimated at baseline and at 6 weeks after NSPT. There were significant differences between study groups regarding serum VCAM-1, IL-6, total cholesterol, LDL $(\mathrm{p}<0.001)$, and HDL $(\mathrm{P}<0.05)$. In group I, the pre-treatment values of all periodontal parameters and biochemical analytes were significantly higher than post-treatment values. At 6 weeks after therapy, both bleeding index and periodontal diseases extension were positively correlated with serum cholesterol, TGs, and LDL. BI was negatively correlated with HDL. It was concluded from the previous findings that chronic periodontitis has the potential to increase systemic inflammation, vascular endothelial biomarkers, and serum lipid profile of affected individuals. Hence, NSPT may reduce the risk of CVS diseases by reducing the systemic inflammation.
\end{abstract}

KEYWORDS: Chronic periodontitis, systemic inflammation, IL-6, VCAM-1, lipid profile, cardiovascular diseases.

* Assistant professor of Oral Medicine and Periodontology, Department of Oral Medicine and Periodontology, Faculty of Dentistry, Mansoura University.

** Professor of Clinical Pathology, Department Clinical Pathology, Faculty of Medicine, Mansoura University. 


\section{INTRODUCTION}

Periodontitis is a chronic inflammation of the periodontal tissues, inducing connective tissue disruption, alveolar bone resorption and finally tooth loss. It is caused by host bacterial interaction resulting in an exaggerated inflammatory response and overexpression of pro-inflammatory cytokines by host cells, such as interleukin-1 $\beta$ (IL-1 $\beta$ ) and tumor necrosis factor- $\alpha$ (TNF- $\alpha$ ), thereby stimulating an inflammatory cascade which triggers matrix metalloproteinases (MMPs) and prostaglandin-E2 (PGE2) formation. ${ }^{(1)}$

Several investigations revealed that periodontal disease is commonly related to atherosclerosis ${ }^{(2,3)}$, myocardial infarction, cerebrovascular disease, and peripheral vascular diseases. ${ }^{(4,5)}$ Cardiovascular diseases remain the main cause of death worldwide and especially in developed countries. ${ }^{(6)}$ Atherosclerosis is the disease mechanism that causes most of cardiovascular diseases. ${ }^{(7)}$ An imbalance of the secretory, regulatory, metabolic and immunological properties of the vascular endothelium are linked to dysfunction of the vascular endothelium and atherogenesis, and associated with increased onset of cardiovascular diseases. ${ }^{\left({ }^{8}\right)}$ Moreover, various studies also have shown the correlation between increased inflammatory markers levels and the occurrence of cardiovascular disease..$^{(9,10)}$

Periodontal disease may be a risk factor for cardiovascular disease through a common underlying pathogenic inflammatory response. Periodontopathogenic bacteria can reach the circulation directly by invading the host tissues. ${ }^{(11)}$ Periodontal infections are associated with repeated bacteremias and endotoxemias; actually, periodontal bacteria have been detected within atheromatous plaques. ${ }^{(12)}$ As a result, the vasculature is exposed continuously to the disseminated pathogens from periodontal lesions, increasing endothelial inflammatory activation and functional impairment. ${ }^{(13)}$
Moreover, lipopolysaccharide (LPS) derived from periodontal Gram-negative bacteria was found to stimulate the host immune cells and as a consequence, pro-inflammation is observed in both cardiovascular disease and periodontitis. ${ }^{(14,15)}$ Recently, periodontal therapy was found to decrease systemic inflammation, improves cardiovascular functions and endothelial function in individuals with periodontal and cardiovascular diseases. ${ }^{(16-20)}$ However, periodontal disease was suggested to be linked with numerous risk factors and biomarkers of cardiovascular diseases, there is considerable heterogeneity in methodology, demographics and results among previous reports..$^{(3,21,22)}$ Hence, the aim of this study is categorized as follows:

1. To evaluate the levels of cardiovascular disease risk markers including IL-6, VCAM-1, and lipids [TGs, HDL, LDL, total cholesterol] in the sera of adults with chronic periodontitis.

2. To assess the relation between periodontal disease extent and severity and settled biomarkers of cardiovascular risk, inflammation and vascular health, in sera of chronic periodontitis patients.

3. To investigate whether the non-surgical periodontal treatment (NSPT) could reduce the levels of cardiovascular disease biomarkers in chronic periodontitis patients.

\section{PATIENTS AND METHODS}

\section{Patient Selection}

A total of 101 individuals were screened in the Periodontology clinics, Faculty of Dentistry, Mansoura University, between July and November, 2016. Thirty seven subjects were excluded; 22 individuals did not meet the inclusion criteria and 15 individuals refused to participate. Sixty four participants were eligible for the study. The selected subjects had no history of any systemic diseases such as hypertension, diabetes mellitus, obesity... etc. The eligible individuals did not receive any previous treatment of chronic periodontitis at least 
6 months or take antibiotics or non-steroidal antiinflammatory drugs 3 months before commencement of the study. Subjects had no obvious source of oral infection. Patients with orthodontic therapy and uncooperative patients were excluded from participation in this study. The study was approved by the Institutional Review Board of Mansoura University.

The enrolled subjects were classified into two groups: chronic periodontitis group (group I): included 32 chronic periodontitis patients, according to Armitage criteria. ${ }^{(23)}$ Their age range was 3653 years (17 males \&15 females). Healthy control group (group II) included 32 adults with clinically healthy periodontium. Their age range was 34-49 years (18 males \& 14 females).

\section{Periodontal Assessment}

The following clinical indices were assessed: Plaque index $(\mathrm{PI})^{(24)}$, papillary Bleeding Index $(\mathrm{BI})^{(25)}$, Gingival Index (GI) ${ }^{(26)}$, Probing Depth (PD), Clinical Attachment Loss (CAL) and eventually Extent and Severity Periodontal Index (ESI) was calculated. In the assessment of the disease extension (E), a site is recognized as periodontally affected when the attachment loss is greater than $1 \mathrm{~mm}$. Thus, a new vector (di) is developed where di $=1$ if $\mathrm{CAL}>1$ and $\mathrm{di}=0$ if $\mathrm{CAL} \leq 1$, otherwise, extension of the disease (E) is presented as the percentage of the actually examined sites which exhibit disease.

Where, $\mathrm{E}$ is the disease extent, $\mathrm{n}$ is the number of actually examined sites, and di is the diseased site which exhibits CAL more than $1 \mathrm{~mm}$.

Severity of periodontal disease (S) is expressed as the mean loss of attachment that is greater than $1 \mathrm{~mm}$.

Where $\mathrm{S}$ is the disease severity, $\mathrm{xi}$ is a measurement of attachment level in $\mathrm{mm}, \mathrm{n}$ is defined as the number of actually examined sites, di is the diseased site which exhibits CAL more than $1 \mathrm{~mm} .{ }^{(27)}$ These clinical indices were measured at baseline in both groups and after 6 weeks in group I following initial periodontal treatment.

\section{Treatment Phase}

Group I patients received nonsurgical periodontal therapy (NSPT), involving oral hygiene instructions, restoration of carious lesions and treatment of food impaction areas, correction of poorly fitting prosthetics and restorations, and hopeless teeth extraction. Scaling and root planing (SRP) were done for all patients in group I by using ultrasonic and hand instruments twice weekly for two weeks. No antibiotics were prescribed after SRP.

\section{Biochemical Assessment}

After an overnight fasting (approximately 12 hours), $4 \mathrm{~mL}$ of venous blood samples were withdrawn from the antecubital fossa of the arm under complete aseptic condition at baseline in both study groups and once again, after 6 weeks of nonsurgical periodontal treatment in group I. The blood samples were left to clot for 20 minutes. Then blood samples were centrifuged at $3000 \mathrm{rpm}$ for 10 minutes. Non-hemolyzed clear sera were separated into 3 aliquots. Two aliquots were kept at $-20 \mathrm{c}$ for analysis of serum IL-6, and VCAM-1. VCAM-1 levels were assayed by specific enzyme linked immuno-sorbent assay (ELISA) kit (Quantikine humans-VCAM-1 research diagnostic system, Europe, Abington, UK). The level of IL-6 in serum samples was assayed by using interleukin 6 (IL-6) ELISA kit (Elabscience, Bethesda, MD, USA). Another aliquot was used for lipid profile: Triglycerides, total cholesterol and HDL, using commercially available kits supplied by SPINREACT (Sant Esteve de bas (GI), Spain). Low-density lipoprotein-cholesterol was calculated using the Friedewald equation: LDL-c=Total cholesterol- HDL-TG/5 (mg/dL). ${ }^{(28)}$

\section{Statistical Analysis of Data}

Data was fed to the computer and analyzed using IBM SPSS software package version 20.0. A power analysis was done before starting the study with type I error $\alpha=0.05, \beta=0.18$ and $(1-\beta)=$ 0.82 . The power was calculated as $p=0.8216$ and the estimated minimum sample size required was 
found to be 18 per each group to achieve a power of $80 \%$. The mean and standard deviation were used to describe quantitative data after testing normality via Kolmogorov-Smirnov test. Student $t$ test was used to compare between the two study groups. The Paired t-test was used to evaluate variation between baseline and after treatment in the test group. Moreover, Pearson correlation was used to correlate 2 normally quantitative variables. The significance of the yielded results was judged at the $5 \%$ level.

\section{RESULTS}

A total of 64 individuals were selected for participation in the study; 32 participants met the inclusion criteria to represent the chronic periodontitis patients (group I) and the remaining 32 individuals represented the control group. One participant of group I and five individuals from group II were lost during the follow-up period. Thus, only 58 participants completed the study and their data were analyzed at the end of the study; group I ( $\mathrm{n}=31)$ and group II $(\mathrm{n}=27)$.

The demographic data and baseline clinical periodontal indices of the study groups were demonstrated in table 1 . There were no statistically significant variations in both groups regarding age and sex. In group I, the plaque index (PI), papillary bleeding index (BI), gingival index (GI), and probing depth (PD) were significantly higher than those of control group $(\mathrm{p}<0.001)$. The average values (mean $\pm \mathrm{SD}$ ) of the extent and severity index (ESI) in chronic periodontitis group were $83.55 \pm 13.6$ and $2.17 \pm 0.26$, respectively.

Table 2 shows the biochemical investigations of the study groups at baseline. Highly statistically significant differences were detected between both groups regarding serum VCAM-1, IL-6, total cholesterol and LDL $(\mathrm{p}<0.001)$. Moreover, HDL mean value of group I was significantly lower than that in the control group $(\mathrm{P}<0.05)$. However, in group I, the mean value of TGs was not significantly different compared to group II ( $\mathrm{P}>0.05)$.
Table 3 exhibits the comparison between pre- and post-treatment periodontal parameters in chronic periodontitis group. The post-treatment mean values of all periodontal indices in group I were significantly higher than pre-treatment parameters $(\mathrm{P}<0.001)$

Table 4 indicates a comparison between pretreatment and post-treatment values of biochemical analytes in chronic periodontitis group. The pre-treatment values of VCAM-1, IL-6, total cholesterol, TGs, HDL $(\mathrm{P}<0.001)$, while LDL $(\mathrm{P}<0.01)$ decreased significantly by NSPT.

In table 5, the correlation between periodontal indices and biochemical analytes at baseline was demonstrated. There was significantly positive correlation between the mean value of PI and the mean value of VCAM-1 and total cholesterol $(\mathrm{P}=0.002,0.046$, respectively). The mean value of GI was positively correlated with the mean value of VCAM-1, total cholesterol, TGs and LDL serum levels at baseline $(\mathrm{P}=0.035,<0.001,<0.001,<0.001$, respectively). The mean value of $\mathrm{BI}$ was positively correlated with the mean values of VCAM-1, total cholesterol, TGs and LDL serum levels $(\mathrm{P}=0.024$, $0.003,0.017$ and 0.013 , respectively).

Moreover, the mean value of PD was positively correlated with the mean values of VCAM-1, LDL, and total cholesterol $(\mathrm{P}=0.02,0.013$, and 0.043 respectively). The mean value of $\mathrm{E}$ value of ESI was positively correlated with the mean values of VCAM-1, total cholesterol, TGs, and LDL ( $\mathrm{P}=0.012$, $0.002,0.002,<0.001$, respectively). Furthermore, $\mathrm{S}$ value of ESI was positively correlated with the mean values of IL-6, total cholesterol, TGs and LDL ( $\mathrm{P}=0.01,0.022,0.006$, and 0.001 , respectively). However, the mean values of GI, BI, PD, E, and $\mathrm{S}$ were negatively correlated with the mean values of HDL $(\mathrm{P}<0.001,=0.004,=0.004,<0.001,=0.01$, respectively) (Table 5).

Table 6 exhibits the correlation between clinical periodontal indices and biochemical measurements at 6 weeks after NSPT. The mean value of BI was 
positively correlated with the mean values of total cholesterol, TGs, and LDL serum levels ( $\mathrm{P}=0.008$, 0.002 , and 0.006 , respectively) and negatively correlated with the mean value of serum HDL
$(\mathrm{P}=0.018)$. There were also positive correlations between the mean value of $\mathrm{E}$ and the mean values of serum total cholesterol, TGs and LDL levels $(\mathrm{P}=0.023,0.006$, and 0.007 , respectively).

TABLE (1) Demographic Data and Baseline Periodontal Indices for Study Groups

\begin{tabular}{|l|c|c|c|}
\hline Parameter & $\begin{array}{c}\text { Group I } \\
\text { (Chronic Periodontitis group) } \\
\mathbf{n = 3 1}(\text { Mean } \mathbf{\text { SD}})\end{array}$ & $\begin{array}{c}\text { Group II } \\
\text { (Healthy control group) } \\
\mathbf{n = 2 7} \text { (Mean } \mathbf{\text { SD}})\end{array}$ & *P value \\
\hline Age (year) & $43 \pm 3.4$ & $41 \pm 2.6$ & NS \\
\hline Sex (M/F) & $17 / 14$ & $15 / 12$ & $<0.001$ \\
\hline PI & $1.96 \pm 0.29$ & $0.53 \pm 0.198$ & $<0.001$ \\
\hline GI & $1.84 \pm 0.44$ & $0.51 \pm 0.12$ & $<0.001$ \\
\hline BI $(\%)$ & $0.89 \pm 0.11$ & $0.41 \pm 0.08$ & $<0.001$ \\
\hline PD (mm) & $2.59 \pm 0.38$ & $0.86 \pm 0.12$ & 0 \\
\hline E $(\%)$ & $83.55 \pm 13.6$ & 0 & 0 \\
\hline S $(\mathbf{m m})$ & $2.17 \pm 0.26$ & 0 & NS \\
\hline
\end{tabular}

*P= Student $t$ test (Statistically significant when $P<0.05)$. NS= non-significant.

$(M / F)=$ male to female ratio, $P I=P l a q u e$ index, $G I=$ Gingival index, $B I=$ Papillary bleeding index, $P D=$ probing depth.

E= Extent of periodontal disease which is expressed by percentage of sites exhibiting the disease i.e., sites showing loss of clinical attachment $(C A L)$.

$S=$ Severity of periodontal disease which is expressed as the mean of CAL.

TABLE (2) Biochemical Measurements of Study Groups at Baseline

\begin{tabular}{|l|c|c|c|}
\hline Biochemical Analyte & $\begin{array}{c}\text { Group I (Chronic Periodontitis group) } \\
\mathbf{n = 3 1}(\text { Mean } \pm \text { SD) }\end{array}$ & $\begin{array}{c}\text { Group II (Healthy control group) } \\
\text { n=27 (Mean } \pm \text { SD) }\end{array}$ & $* \mathbf{P}$ \\
\hline VCAM-1 (pg/mL) & $574.4 \pm 110.97$ & $350.0 \pm 42.17$ & $<0.001$ \\
\hline IL-6 (pg/mL) & $19.28 \pm 4.26$ & $10.68 \pm 3.17$ & $<0.001$ \\
\hline Total Cholesterol (mg/dL) & $190.4 \pm 17.98$ & $162.0 \pm 9.59$ & $<0.001$ \\
\hline TGs (mg/dL) & $95.4 \pm 18.73$ & $98.2 \pm 25.88$ & $>0.05$ \\
\hline HDL (mg/dL) & $52.0 \pm 7.21$ & $58.4 \pm 8.17$ & $<0.05$ \\
\hline LDL (mg/dL) & $120.8 \pm 21.51$ & $83.8 \pm 15.92$ & $<0.001$ \\
\hline
\end{tabular}

*P=Student $t$ test (Statistically significant when $P<0.05) . \quad$ VCAM-1=Vascular cell adhesion molecule-1.

IL-6=Interleukin-6. TGs=Triglycerides. HDL=High-density lipoprotein cholesterol .

$L D L=$ Low-density lipoprotein cholesterol. 
TABLE (3) Comparison between Pre- and Post- Treatment Measurements of Periodontal Indices in Chronic Periodontitis Group

\begin{tabular}{|l|c|c|c|}
\hline Parameter & $\begin{array}{c}\text { Pre- Treatment } \\
(\text { Mean } \mathbf{+ S D})\end{array}$ & $\begin{array}{c}\text { Post-Treatment } \\
(\text { Mean } \pm \text { SD) }\end{array}$ & $* * \mathbf{P}$ \\
\hline PI & $1.96 \pm 0.29$ & $0.97 \pm 0.31$ & $<0.001$ \\
\hline GI & $1.84 \pm 0.44$ & $0.99 \pm 0.29$ & $<0.001$ \\
\hline BI $(\%)$ & $0.89 \pm 0.11$ & $0.51 \pm 0.17$ & $<0.001$ \\
\hline PD $(\mathbf{m m})$ & $2.59 \pm 0.38$ & $1.93 \pm 0.23$ & $<0.001$ \\
\hline E $(\%)$ & $83.55 \pm 13.6$ & $60.99 \pm 18.18$ & $<0.001$ \\
\hline S $(\mathbf{m m})$ & $2.17 \pm 0.26$ & $1.69 \pm 0.18$ & $<0.001$ \\
\hline
\end{tabular}

** P= Paired t test (Statistically significant when $P<0.05$ ).

TABLE (4) Comparison between Pre- and Post-Treatment Biochemical Measurements in Chronic Periodontitis Group

\begin{tabular}{|l|c|c|c|}
\hline \multicolumn{1}{|c|}{ Biochemical Analyte } & $\begin{array}{c}\text { Pre- Treatment } \\
(\text { Mean } \mathbf{\pm S D})\end{array}$ & $\begin{array}{c}\text { Post-Treatment } \\
(\text { Mean } \pm \text { SD) }\end{array}$ & $* * \mathbf{P}$ \\
\hline VCAM-1 (pg/mL) & $574.4 \pm 110.97$ & $371.6 \pm 51.14$ & $<0.001$ \\
\hline IL-6 (pg/mL) & $19.28 \pm 4.26$ & $15.28 \pm 3.44$ & $<0.001$ \\
\hline Total Cholesterol (mg/dL) & $190.4 \pm 17.98$ & $167.53 \pm 23.25$ & $<0.001$ \\
\hline TGs $(\mathbf{m g} / \mathbf{d L})$ & $95.4 \pm 18.73$ & $80.2 \pm 14.43$ & $<0.001$ \\
\hline HDL $(\mathbf{m g} / \mathbf{d L})$ & $52.0 \pm 7.21$ & $45.53 \pm 6.3$ & $<0.001$ \\
\hline LDL $(\mathbf{m g} / \mathbf{d L})$ & $120.8 \pm 21.51$ & $105.2 \pm 29.39$ & $<0.01$ \\
\hline
\end{tabular}

** $P=$ Paired $t$ test (Statistically significant when $P<0.05$ ).

TABLE (5) Correlation between Clinical Periodontal Indices and Biochemical Measurements at Baseline

\begin{tabular}{|c|c|c|c|c|c|c|c|}
\hline Parameter & & VCAM-1 & IL-6 & Total Cholesterol & TGs & HDL & LDL \\
\hline \multirow{2}{*}{ PI } & $\mathrm{r}$ & 0.738 & 0.049 & 0.523 & 0.1 & -0.434 & 0.299 \\
\cline { 2 - 8 } & $\mathrm{p}$ & $0.002^{*}$ & 0.863 & $0.046^{*}$ & 0.724 & 0.11 & 0.279 \\
\hline \multirow{3}{*}{ GI } & $\mathrm{r}$ & 0.547 & 0.34 & 0.821 & 0.763 & -0.798 & 0.791 \\
\cline { 2 - 8 } & $\mathrm{p}$ & $0.035^{*}$ & 0.22 & $<0.001^{*}$ & $<0.001^{*}$ & $<0.001^{*}$ & $<0.001^{*}$ \\
\hline \multirow{2}{*}{ BI } & $\mathrm{r}$ & 0.579 & 0.209 & 0.709 & 0.604 & -0.697 & 0.626 \\
\cline { 2 - 8 } & $\mathrm{p}$ & $0.024 *$ & 0.454 & $0.003^{*}$ & $0.017^{*}$ & $0.004^{*}$ & $0.013^{*}$ \\
\hline \multirow{2}{*}{ PD } & $\mathrm{r}$ & 0.584 & 0.378 & 0.529 & 0.424 & -0.693 & 0.626 \\
\cline { 2 - 8 } & $\mathrm{p}$ & $0.02^{*}$ & 0.165 & $0.043^{*}$ & 0.115 & $0.004^{*}$ & $0.013^{*}$ \\
\hline \multirow{2}{*}{$\mathbf{E}$} & $\mathrm{r}$ & 0.628 & 0.150 & 0.727 & 0.738 & -0.821 & 0.793 \\
\cline { 2 - 8 } & $\mathrm{p}$ & $0.012^{*}$ & 0.593 & $0.002^{*}$ & $0.002^{*}$ & $<0.001^{*}$ & $<0.001^{*}$ \\
\hline \multirow{2}{*}{$\mathbf{S}$} & $\mathrm{r}$ & 0.392 & 0.644 & 0.586 & 0.67 & -0.638 & 0.747 \\
\cline { 2 - 8 } & $\mathrm{p}$ & 0.149 & $0.01 *$ & $0.022^{*}$ & $0.006^{*}$ & $0.01 *$ & $0.001^{*}$ \\
\hline
\end{tabular}

$* P=$ statistically significant when $P<0.05$. 
Table (6) Correlation between Clinical Periodontal Indices and Biochemical Measurements at 6 Weeks after Non-Surgical Periodontal Treatment

\begin{tabular}{|c|c|c|c|c|c|c|c|}
\hline Parameter & & VCAM-1 & IL-6 & Total Cholesterol & TGs & HDL & LDL \\
\hline \multirow{2}{*}{ PI } & $\mathrm{r}$ & 0.175 & 0.247 & -0.15 & -0.165 & 0.155 & -0.026 \\
\hline & $\mathrm{p}$ & 0.533 & 0.375 & 0.594 & 0.55 & 0.581 & 0.927 \\
\hline \multirow{2}{*}{ GI } & $\mathrm{r}$ & 0.005 & -0.048 & 0.275 & 0.337 & -0.231 & 0.208 \\
\hline & $\mathrm{p}$ & 0.986 & 0.864 & 0.322 & 0.22 & 0.407 & 0.456 \\
\hline \multirow{2}{*}{ BI } & $\mathrm{r}$ & 0.246 & 0.271 & 0.659 & 0.738 & -0.601 & 0.671 \\
\hline & $\mathrm{p}$ & 0.377 & 0.329 & $0.008^{*}$ & $0.002 *$ & $0.018 *$ & $0.006^{*}$ \\
\hline \multirow{2}{*}{ PD } & $\mathrm{r}$ & 0.129 & 0.114 & 0.369 & 0.289 & -0.451 & 0.148 \\
\hline & $\mathrm{p}$ & 0.646 & 0.685 & 0.176 & 0.296 & 0.09 & 0.599 \\
\hline \multirow{2}{*}{$\mathbf{E}$} & $\mathrm{r}$ & 0.506 & 0.256 & 0.583 & 0.676 & -0.428 & 0.662 \\
\hline & $\mathrm{p}$ & 0.054 & 0.356 & $0.023^{*}$ & $0.006^{*}$ & 0.11 & $0.007^{*}$ \\
\hline \multirow{2}{*}{$\mathbf{S}$} & $\mathrm{r}$ & -0.217 & 0.145 & 0.077 & 0.336 & -0.37 & 0.29 \\
\hline & $\mathrm{p}$ & 0.438 & 0.606 & 0.785 & 0.221 & 0.174 & 0.295 \\
\hline
\end{tabular}

*P= statistically significant when $P<0.05$.

\section{DISCUSSION}

Low grade systemic inflammation was proved to increase liability for coronary artery disease (CAD) and ischemic stroke. ${ }^{(29-35)}$ The pro-inflammatory state is represented by serum elevation of acutephase proteins and immune mediators: interleukins (IL-1, IL-4, IL-6, IL-18), tumor necrosis factor- $\alpha$ (TNF- $\alpha$ ), metalloproteinase-9 (MMP-9), haptoglobin, amyloid A, platelet-activating factor (PAF), and alpha 1 anti-chymotrypsin. ${ }^{(14)}$

In this interventional study, the mean value of serum IL- 6 of chronic periodontitis group was significantly higher than that of healthy individuals. These results were coincidental with those of another study who observed IL-6 formation by mononuclear cells present in chronic inflamed periodontal tissues ${ }^{(36)}$ and in contrast to Shaker and Hashem study ${ }^{(37)}$ who found that the serum IL-6 level of chronic periodontitis subjects was not significantly different than that of healthy control. This might be explained as Shaker and Hashem results of IL-6 were skewed (not normally distributed) so, the data were expressed as median value and range.

In periodontitis patients, the increased serum IL-6 levels can be explained by bacterial LPS stimulation of the expression of IL-6 via the host immune system. ${ }^{(38,39)}$ Roth et al study, 2007, demonstrated an elevated IL- 6 production by endothelial cells of the aorta after $P$. gingivalis infection. ${ }^{(40)}$ Increased IL-6 was found to induce visfatin expression that increases the formation of the adhesion and inflammatory proteins, as leukocyte endothelial adhesion molecules (E-Selectin), intercellular adhesion molecule 1 (ICAM-1), and VCAM1 which trigger PGE2 synthesis and increase periodontal disease severity. ${ }^{(41)}$ 
IL-6 and other pro-inflammatory mediators are formed locally in periodontal lesions and have the ability to escape into the blood stream. These molecules could affect blood vessel walls and the liver. Furthermore, the stimulated liver secretes excess amount of C-reactive protein (CRP), complement and prothrombotic molecules, as plasminogen, von-Willebrand factor, and fibrinogen. Thus, the increased serum level of locally produced proinflammatory cytokines by periodontal lesions and acute-phase reactants formed by liver can exaggerate endothelial inflammation and induce atherosclerosis. ${ }^{(17)}$

IL-6 helps the adhesion of leukocyte to the wall of atherosclerosis-liable vessel. IL- 6 was found to facilitate attachment of lymphocytes mainly CD4+ to the endothelium of umbilical vein and to increase the formation of adhesion molecules on endothelial cells. ${ }^{(42)}$ IL-6 was proved to exacerbate smooth muscle cell proliferation and migration ${ }^{(43)}$ and appears to act a fundamental role in the fatty streak formation. ${ }^{(10)}$

Moreover, it was detected in this study that serum IL-6 level in chronic periodontitis patients was decreased significantly by non-surgical periodontal therapy. These results were in accordance with the findings of Solomon et al study ${ }^{(44)}$ and Almaghlouth et al study ${ }^{(45)}$ and in contrast to other studies. ${ }^{(46,47)}$

The reduction of IL- 6 by nonsurgical periodontal therapy can be explained by the observed reduction of all periodontal index scores by periodontal therapy and as a result fewer periodontal pathogens and fewer bacterial products were escaped to the blood stream, resulting in less pro-inflammatory IL-6 in serum.

In this study, the serum VCAM-1 level in chronic periodontitis patients was significantly higher than the control subjects. This result was consistent with several studies reporting that VCAM-1expression is increased by $P$. gingivalis LPS in endothelial cells. ${ }^{(48-50)}$ However, other studies did not find any increase in VCAM-1 expression by $P$. gingivalis
LPS. ${ }^{(51,52)}$ The findings of the present study also showed that the serum VCAM-1 level decreased significantly by nonsurgical periodontal treatment. This result was in agreement with a study that demonstrated reduced VCAM-1 expression and macrophages/monocytes infiltration in the vascular wall in mice received nonsurgical periodontal treatment. ${ }^{(53)}$ These previous results could be explained by periodontal pathogens invade vascular endothelial cells in order to evade the immune cells. ${ }^{(54)}$ Endothelial invasion by $P$. gingivalis is facilitated by hemagglutinin A (HagA $)^{(55)}$, hemagglutinin B (HagB) ${ }^{(56)}$, and fimbriae A (Fim A). Fim A increases different adhesion molecules expression on the endothelial cells of blood vessels and inflammatory mediators expression as IL-6, IL-8, and cyclooxygenase-2 (COX-2). ${ }^{(51,57-59)}$ In fact, LPS and Fim A could coordinate in the proinflammatory stimulation of arterial endothelium by $P$. gingivalis. ${ }^{(60)}$ Aggregatebacter actinomycetemcomitans (and its leukotoxin) also up-regulate the formation of adhesion molecules (as VCAM-1, ICAM-1, and P-selectin), however, in lesser amount. ${ }^{(60,61)}$

Moreover, the pro-inflammatory cytokines as IL-1, IL-6 and CRP decrease the nitric oxide synthase (NOS) secretion by endothelial cells ${ }^{(62)}$, promoting endothelial expression of NADPH oxidases and increase the endothelial expression of VCAM-1, ICAM-1, E-selectin and P-selectin. ${ }^{(63,64)}$ Soluble CAMs forms were detected in serum and associated with endothelial dysfunction. ${ }^{(65)}$ Periodontal pathogens were found to increase the endothelial synthesis of adhesion and chemo-attractant molecules, stimulating the adhesion of monocytes and different leukocytes to the surface of endothelial cells to form the atherosclerotic plaque..$^{(10,66,67)}$

Dyslipidemia (increased serum triglycerides, LDL, and very low density lipoproteins (vLDL) is actually associated with not only fatty foods, but also inflammatory processes. In fact, proinflammatory cytokines as IL- 6 , IL- $1 \beta$, and TNF- $\alpha$ increase plasma VLDL/TG levels by increasing 
hepatic lipogenesis ${ }^{(68,69)}$ and lowering the clearance of VLDL-TG by decreasing the activity of the lipoprotein lipase. ${ }^{(70)}$

In this study, untreated chronic periodontitis patients at baseline showed significant increase in total serum cholesterol, LDL, and triglycerides (TGs) and decreased HDL. These findings were in agreement with the results of Schenkein and Loos, 2013.(14) In patients with chronic PD, $P$. gingivalis LPS is chiefly accompanied with proatherogenic LDL. ${ }^{(71)}$ LPS-LDL assemblies induce LDLdependent proinflamation (72) and stimulate macrophages to engulf LDL cholesterol. ${ }^{(73,74)}$ In macrophages, LPS derived from $P$. gingivalis increases CD 36 which acts as a scavenger receptor for LDL and oxidized LDL ${ }^{(75,76)}$ and as a result, LDL and oxLDL increased in macrophages. Moreover, other periodontal bacteria, such as T. forsythia (77) and A. actinomycetemcomitans ${ }^{(78)}$ were found to induce foam cell formation.

In addition, in periodontitis patients, oxLDL can be formed by oxidation of LDL and autoantibodies to oxLDL have been detected. ${ }^{(79)}$ Normally, macrophages could be able to control homeostasis of serum cholesterol and lipoprotein by wellcontrolled taking up and liberating into the blood. (80) Periodontal bacteria and their endotoxins can affect lipid metabolism in macrophages. LPS decreases $\mathrm{X}$ receptors formation in the liver, which are the main inducer of lipid catabolism in macrophages. ${ }^{(78)}$ Thus, periodontitis patients are usually accompanied with dyslipidemia, and more susceptible for increased atherogenesis, especially when associated with LPS.

Furthermore, in this study, dyslipidemia in periodontitis patients was reduced after periodontal therapy. This result was coincidental with the result of Teeuw et al., 2014. ${ }^{(80)}$ This represents another explanation that periodontitis is actually associated with dyslipidemia and treatment of periodontitis could be an essential part of a group of treatments, to decrease the risk for bacteremia and prevent further development of atherosclerotic lesions.

\section{CONCLUSIONS}

1. Chronic periodontitis may add to the systemic inflammatory burden (IL-6), increase vascular endothelial biomarker (VCAM-1) and serum lipid profile of affected individuals; thereby increasing the risk of cardiovascular disease.

2. Periodontal disease extent and severity are correlated with serum markers of systemic inflammation, vascular health, and lipid profile.

3. The nonsurgical periodontal treatment (NSPT) may decrease the systemic inflammation and the risk of CVS disease in periodontitis patients.

\section{RECOMMENDATIONS}

Further studies with larger sample size are needed to prove that inflammatory markers may be valuable predictors of eventual cardiovascular disease in chronic periodontitis patients and individuals at risk for atherosclerotic disease. Finally, the findings of this study might encourage greater mutual effort between medical professionals and dentists to make periodontal therapy ordinary routine work in the treatment of cardiovascular disease.

\section{REFERENCES}

1. Heaton B and Dietrich T: Causal theory and the etiology of periodontal diseases. Periodontol 2000,2012;58,26-36.

2. Fifer KM, Qadir S, Subramanian S, Vijayakumar J, Figueroa AL, Truong QA, Hoffmann U, Brady TJ and Tawakol A: Positron emission tomography measurement of periodontal 18F-fluorodeoxyglucose uptake is associated with histologically determined carotid plaque inflammation. J Am Coll Cardiol,2011;57,971-976.

3. Lockhart PB, Bolger AF, Papapanou PN, Osinbowale O, Trevisan M, Levison ME, Taubert KA, Newburger JW, Gornik HL, Gewitz MH, Wilson WR, Smith SC and Baddour LM: Periodontal disease and atherosclerotic vascular disease: does the evidence support an independent association?: a scientific statement from the American Heart Association. Circulation,2012;125,2520-2544.

4. Stassen FR, Vainas $\mathrm{T}$ and Bruggeman CA: Infection and atherosclerosis. An alternative view on an outdated hypothesis. Pharmacol Rep,2008;60,85-92. 
5. Bahekar AA, Singh S, Saha S, Molnar J and Arora R: The prevalence and incidence of coronary heart disease is significantly increased in periodontitis: a meta-analysis. Am Heart J,2007;154,830-837.

6. Bautista LE, Orostegui M, Vera LM, Prada GE, Orozco LC and Herran OF: Prevalence and impact of cardiovascular risk factors in Bucaramanga, Colombia: results from the Countrywide Integrated Noncommunicable Disease Intervention Programme (CINDI/CARMEN) baseline survey. Eur J Cardiovasc Prev Rehabil,2006;13,769-775.

7. Pepine CJ: The effects of angiotensin-converting enzyme inhibition on endothelial dysfunction: potential role in myocardial ischemia. Am J Cardiol,1998; 82,23S-27S .

8. Faulx MD, Wright AT and Hoit BD: Detection of endothelial dysfunction with brachial artery ultrasound scanning. Am Heart J,2003;145, 943-951.

9. Packard RR and Libby P: Inflammation in atherosclerosis: from vascular biology to biomarker discovery and risk prediction. Clin Chem,2008;54, 24-38.

10. Hansson GK: Inflammation, atherosclerosis, and coronary artery disease. N Engl J Med,2005; 352, 1685-1695.

11. Offenbacher S, Elter JR, Lin D and Beck JD: Evidence for periodontitis as a tertiary vascular infection. J Int Acad Periodontol,2005;7,39-48.

12. Haraszthy VI, Zambon JJ, Trevisan M, Zeid M and Genco RJ: Identification of periodontal pathogens in atheromatous plaques. J Periodontol,2000;71,1554-1560

13. Skilton MR, Maple-Brown LJ, Kapellas K, Celermajer DS, Bartold M, Brown A, O'Dea K, Slade GD and Jamieson LM: The effect of a periodontal intervention on cardiovascular risk markers in Indigenous Australians with periodontal disease: the PerioCardio study. BMC Public Health,2011;11, 729.

14. Schenkein HA and Loos BG: Inflammatory mechanisms linking periodontal diseases to cardiovascular diseases. J Clin Periodontol,1013; 40 Suppl 14, S51-69.

15. Nogueira-Filho $G$ and Tenenbaum HC: So why do we call it the oral-systemic health connection? J Can Dent Assoc,2011;77,b36.

16. Seinost G, Wimmer G, Skerget M, Thaller E, Brodmann M, Gasser R, Bratschko RO and Pilger E: Periodontal treatment improves endothelial dysfunction in patients with severe periodontitis. Am Heart J,2005;149,10501054.
17. Tonetti MS, D’Aiuto F, Nibali L, Donald A, Storry C, Parkar M, Suvan J, Hingorani AD, Vallance P,and Deanfield J: Treatment of periodontitis and endothelial function. $\mathrm{N}$ Engl J Med,2007;356, 911-920.

18. D’Aiuto F, Parkar M, Nibali L, Suvan J, Lessem J,and Tonetti MS: Periodontal infections cause changes in traditional and novel cardiovascular risk factors: results from a randomized controlled clinical trial. Am Heart J,2006;151,977-984.

19. D’Aiuto F, Nibali L, Parkar M, Suvan J,and Tonetti MS: Short-term effects of intensive periodontal therapy on serum inflammatory markers and cholesterol. J Dent Res,2005;84,269-273.

20. Orlandi M, Suvan J, Petrie A, Donos N, Masi S, Hingorani A, Deanfield J,and D'Aiuto F: Association between periodontal disease and its treatment, flow-mediated dilatation and carotid intima-media thickness: a systematic review and meta-analysis. Atherosclerosis,2014;236 39-46.

21. Hujoel PP, Drangsholt M, Spiekerman C, and DeRouen TA: Periodontal disease and coronary heart disease risk. JAMA,2000;284, 1406-1410.

22. Howell TH, Ridker PM, Ajani UA, Hennekens CH, and Christen WG: Periodontal disease and risk of subsequent cardiovascular disease in U.S. male physicians. J Am Coll Cardiol,2001;37, 445-450.

23. Armitage GC: Development of a classification system for periodontal diseases and conditions. Ann Periodontol,1999;4, 1-6.

24. Silness J, and Loe H: Periodontal Disease in Pregnancy. II. Correlation between Oral Hygiene and Periodontal Condtion. Acta Odontol Scand ,1964;22, 121-135.

25. Ainamo J,and Bay I: Problems and proposals for recording gingivitis and plaque. Int Dent J,1975;25, 229-235.

26. Loe H, and Silness J: Periodontal Disease in Pregnancy. I. Prevalence and Severity. Acta Odontol Scand,1963;21, 533-551.

27. Carlos JP, Wolfe MD,and Kingman A: The extent and severity index: a simple method for use in epidemiologic studies of periodontal disease. J Clin Periodontol,1986;13, 500-505.

28. Friedewald WT, Levy RI,and Fredrickson DS: Estimation of the concentration of low-density lipoprotein cholesterol in plasma, without use of the preparative ultracentrifuge. Clin Chem,1972;18, 499-502. 
29. Friedewald VE, Kornman KS, Beck JD, Genco R, Goldfine A, Libby P, Offenbacher S, Ridker PM, Van Dyke TE, and Roberts WC:The American Journal of Cardiology and Journal of Periodontology Editors' Consensus: periodontitis and atherosclerotic cardiovascular disease. Am J Cardiol,2009;104, 59-68.

30. Andersen NN, and Jess T: Risk of cardiovascular disease in inflammatory bowel disease. World $\mathrm{J}$ Gastrointest Pathophysiol,2014;5, 359-365.

31. Garcia-Gomez C, Bianchi M, de la Fuente D, Badimon L, Padro T, Corbella E, and Pinto X: Inflammation, lipid metabolism and cardiovascular risk in rheumatoid arthritis: A qualitative relationship? World J Orthop ,2014;5, 304-31.

32. Pearson TA, Mensah GA, Alexander RW, Anderson JL, Cannon RO, 3rd, Criqui M, Fadl YY, Fortmann SP, Hong Y, Myers GL, Rifai N, Smith SC, Jr., Taubert K, Tracy RP,and Vinicor F: Markers of inflammation and cardiovascular disease: application to clinical and public health practice: A statement for healthcare professionals from the Centers for Disease Control and Prevention and the American Heart Association. Circulation,2003;107, 499-511.

33. Koenig W: High-sensitivity C-reactive protein and atherosclerotic disease: from improved risk prediction to risk-guided therapy. Int J Cardiol,2013;168, 5126-5134.

34. Emerging Risk Factors C, Kaptoge S, Di Angelantonio E, Lowe G, Pepys MB, Thompson SG, Collins R, Danesh J: $\mathrm{C}$-reactive protein concentration and risk of coronary heart disease, stroke, and mortality: an individual participant meta-analysis. Lancet,2010;375, 132-140.

35. Ridker PM, Cannon CP, Morrow D, Rifai N, Rose LM, McCabe $\mathrm{CH}$, Pfeffer MA, and Braunwald E: C-reactive protein levels and outcomes after statin therapy. N Engl J Med,2005;352, 20-28.

36. Fujihashi K, Beagley KW, Kono Y, Aicher WK, Yamamoto M, DiFabio S, Xu-Amano J, McGhee JR, and Kiyono H: Gingival mononuclear cells from chronic inflammatory periodontal tissues produce interleukin (IL)-5 and IL-6 but not IL-2 and IL-4. Am J Pathol,1993;142, 1239-1250.

37. Shaker ZF, and Hashem BH: Study the role of proinflammatory and anti- inflammatory cytokines in Iraqi chronic periodontitis patients. J. Bagh College Dentistry, 2012;24, 1-7.

38. Noh MK, Jung M, Kim SH, Lee SR, Park KH, Kim DH, Kim HH, and Park YG: Assessment of IL-6, IL-8 and TNF-alpha levels in the gingival tissue of patients with periodontitis. Exp Ther Med,2013; 6, 847-851.
39. Yucel-Lindberg T, and Bage T: Inflammatory mediators in the pathogenesis of periodontitis. Expert Rev Mol Med, $2013 ; 15, \mathrm{e} 7$.

40. Roth GA, Moser B, Roth-Walter F, Giacona MB, Harja E, Papapanou PN, Schmidt AM, and Lalla E: Infection with a periodontal pathogen increases mononuclear cell adhesion to human aortic endothelial cells. Atherosclerosis ,2007;190 271-281.

41. Raghavendra NM, Pradeep AR, Kathariya R, Sharma A, Rao NS, and Naik SB: Effect of non surgical periodontal therapy on gingival crevicular fluid and serum visfatin concentration in periodontal health and disease. Dis Markers,2012;32,383-388.

42. Watson C, Whittaker S, Smith N, Vora AJ, Dumonde DC, and Brown KA: IL-6 acts on endothelial cells to preferentially increase their adherence for lymphocytes. Clin Exp Immunol,1996;105, 112-119.

43. Ikeda U, Ikeda M, Oohara T, Oguchi A, Kamitani T, Tsuruya Y,and Kano S: Interleukin 6 stimulates growth of vascular smooth muscle cells in a PDGF-dependent manner. Am J Physio, 1991; 260, H1713-1717.

44. Solomon SD, and Pfeffer MA: The Future of Clinical Trials in Cardiovascular Medicine. Circulation, 2016;133, 2662-2670.

45. Almaghlouth AA, Cionca N, Cancela JA, Decaillet F, Courvoisier DS, Giannopoulou C,and Mombelli A: Effect of periodontal treatment on peak serum levels of inflammatory markers. Clin Oral Investig,2014;18, 2113-2121.

46. Ide M, McPartlin D, Coward PY, Crook M, Lumb P, and Wilson RF: Effect of treatment of chronic periodontitis on levels of serum markers of acute-phase inflammatory and vascular responses. J Clin Periodontol,2003;30, 334-340.

47. Yamazaki K, Honda T, Oda T, Ueki-Maruyama K, Nakajima $\mathrm{T}$, Yoshie H,and Seymour GJ: Effect of periodontal treatment on the C-reactive protein and proinflammatory cytokine levels in Japanese periodontitis patients. J Periodontal Res,2005;40, 53-58.

48. Khlgatian M, Nassar H, Chou HH, Gibson FC, and Genco CA: Fimbria-dependent activation of cell adhesion molecule expression in Porphyromonas gingivalis-infected endothelial cells. Infect Immun,2002;70, 257-267.

49. Nakamura N, Yoshida M, Umeda M, Huang Y, Kitajima S, Inoue Y, Ishikawa I, and Iwai T: Extended exposure of lipopolysaccharide fraction from Porphyromonas gingivalis 
facilitates mononuclear cell adhesion to vascular endothelium via Toll-like receptor-2 dependent mechanism. Atherosclerosis,2008;196, 59-67.

50. Andrukhov O, Steiner I, Liu S, Bantleon HP, Moritz A, and Rausch-Fan X: Different effects of Porphyromonas gingivalis lipopolysaccharide and TLR2 agonist Pam3CSK 4 on the adhesion molecules expression in endothelial cells. Odontology,2015;103, 19-26.

51. Takahashi Y, Davey M, Yumoto H, Gibson FC,3rd, and Genco CA: Fimbria-dependent activation of pro-inflammatory molecules in Porphyromonas gingivalis infected human aortic endothelial cells. Cell Microbiol,2006;8, 738-757.

52. Honda T, Oda T, Yoshie $\mathrm{H}$, and Yamazaki K: Effects of Porphyromonas gingivalis antigens and proinflammatory cytokines on human coronary artery endothelial cells. Oral Microbiol Immunol,2005,20, 82-88.

53. Cui D, Li H, Lei L, Chen C,and Yan F: Nonsurgical periodontal treatment reduced aortic inflammation in ApoE(-/-) mice with periodontitis. Springerplus,2016;5, 940 .

54. Progulske-Fox A, Kozarov E, Dorn B, Dunn W, Jr., Burks $\mathrm{J}$, and $\mathrm{Wu} \mathrm{Y}$ : Porphyromonas gingivalis virulence factors and invasion of cells of the cardiovascular system. J Periodontal Res,1999;34, 393-399.

55. Belanger M, Kozarov E, Song H, Whitlock J, and Progulske-Fox A: Both the unique and repeat regions of the Porphyromonas gingivalis hemagglutin A are involved in adhesion and invasion of host cells. Anaerobe,2012;18, 128-134.

56. Song H, Belanger M, Whitlock J, Kozarov E, and ProgulskeFox A: Hemagglutinin B is involved in the adherence of Porphyromonas gingivalis to human coronary artery endothelial cells. Infect Immun,2005;73, 7267-7273.

57. Nassar H, Chou HH, Khlgatian M, Gibson FC, Van Dyke TE, and Genco CA: Role for fimbriae and lysinespecific cysteine proteinase gingipain $\mathrm{K}$ in expression of interleukin-8 and monocyte chemoattractant protein in Porphyromonas gingivalis-infected endothelial cells. Infect Immun,2002;70, 268-276.

58. Chou HH, Yumoto H, Davey M, Takahashi Y, Miyamoto T, Gibson FC, 3rd,and Genco CA: Porphyromonas gingivalis fimbria-dependent activation of inflammatory genes in human aortic endothelial cells. Infect Immun,2005;73, $5367-5378$
59. Ho YS, Lai MT, Liu SJ, Lin CT, Naruishi K, Takashiba $\mathrm{S}$, and Chou $\mathrm{HH}$ : Porphyromonas gingivalis fimbriaedependent interleukin- 6 autocrine regulation by increase of gp130 in endothelial cells. J Periodontal Res,2009;44, $550-556$.

60. Niu J,and Kolattukudy PE: Role of MCP-1 in cardiovascular disease: molecular mechanisms and clinical implications. Clin Sci (Lond),2009;117, 95-109.

61. Dietmann A, and Millonig A, Combes V, Couraud PO, Kachlany SC, and Grau GEL: Effects of Aggregatibacter actinomycetemcomitans leukotoxin on endothelial cells. Microb Pathog,2013; 61-62, 43-50.

62. Zhang J, Patel JM, Li YD, and Block ER: Proinflammatory cytokines downregulate gene expression and activity of constitutive nitric oxide synthase in porcine pulmonary artery endothelial cells. Res Commun Mol Pathol Pharmacol,1997;96, 71-87.

63. Papapanagiotou D, Nicu EA, Bizzarro S, Gerdes VE, Meijers JC, Nieuwland R, van der Velden U, and Loos BG: Periodontitis is associated with platelet activation. Atherosclerosis ,2009;202, 605-611.

64. Burger D, and Touyz RM. Cellular biomarkers of endothelial health: microparticles, endothelial progenitor cells, and circulating endothelial cells. J Am Soc Hypertens,2012; 6 , 85-99.

65. Hajishengallis G, Wang M, Harokopakis E, Triantafilou $\mathrm{M}$,and Triantafilou K: Porphyromonas gingivalis fimbriae proactively modulate beta 2 integrin adhesive activity and promote binding to and internalization by macrophages Infect Immun,2006;74, 5658-5666.

66. Hashizume $\mathrm{T}$, Kurita-Ochiai $\mathrm{T}$, and Yamamoto $\mathrm{M}$ : Porphyromonas gingivalis stimulates monocyte adhesion to human umbilical vein endothelial cells. FEMS Immunol Med Microbiol,2011;62, 57-65.

67. Feingold KR, and Grunfeld C: Role of cytokines in inducing hyperlipidemia. Diabetes,1992;41 Suppl 2,97-101.

68. Feingold KR, and Grunfeld C: Tumor necrosis factor-alpha stimulates hepatic lipogenesis in the rat in vivo. J Clin Invest ,1987;80, 184-190.

69. Feingold KR, Staprans I, Memon RA, Moser AH, Shigenaga JK, Doerrler W, Dinarello CA, and Grunfeld C: Endotoxin rapidly induces changes in lipid metabolism that produce hypertriglyceridemia: low doses stimulate hepatic triglyceride production while high doses inhibit clearance. J Lipid Res,1992;33, 1765-1776. 
70. Kallio KA, Buhlin K, Jauhiainen M, Keva R, Tuomainen AM, Klinge B, Gustafsson A, and Pussinen PJ: Lipopolysaccharide associates with pro-atherogenic lipoproteins in periodontitis patients. Innate Immun, 2008;14, 247-253.

71. Kallio KA, Hyvarinen K, Kovanen PT, Jauhiainen M, and Pussinen PJ: Very low density lipoproteins derived from periodontitis patients facilitate macrophage activation via lipopolysaccharide function. Metabolism,2013;62, 661-668.

72. Qi M, Miyakawa H, and Kuramitsu HK: Porphyromonas gingivalis induces murine macrophage foam cell formation. Microb Pathog,2003;35, 259-267.

73. Miyakawa H, Honma K, Qi M,and Kuramitsu HK: Interaction of Porphyromonas gingivalis with low-density lipoproteins: implications for a role for periodontitis in atherosclerosis. J Periodontal Res,2004;39, 1-9.

74. Li XY, Wang C, Xiang XR, Chen FC, Yang CM, and $\mathrm{Wu}$ J: Porphyromonas gingivalis lipopolysaccharide increases lipid accumulation by affecting CD36 and ATPbinding cassette transporter A1 in macrophages. Oncol Rep,2013;30 1329-1336.

75. Brown PM, Kennedy DJ, Morton RE, and Febbraio M: CD36/SR-B2-TLR2 Dependent Pathways Enhance
Porphyromonas gingivalis Mediated Atherosclerosis in the Ldlr KO Mouse Model. PLoS One,2015;10, e0125126.

76. Lee HR, Jun HK, and Choi BK: Tannerella forsythia BspA increases the risk factors for atherosclerosis in $\mathrm{ApoE}(-/-)$ mice. Oral Dis,2014;20, 803-808.

77. Lakio L, Lehto M, Tuomainen AM, Jauhiainen M, Malle E, Asikainen S, and Pussinen PJ: Pro-atherogenic properties of lipopolysaccharide from the periodontal pathogen Actinobacillus actinomycetemcomitans. J Endotoxin Res, 2006;12, 57-64.

78. Schenkein HA, Berry CR, Burmeister JA, Brooks CN, Best AM, and Tew JG: Locally produced anti-phosphorylcholine and anti-oxidized low-density lipoprotein antibodies in gingival crevicular fluid from aggressive periodontitis patients. J Periodontol,2004;75, 146-153.

79. Graham A: Mitochondrial regulation of macrophage cholesterol homeostasis. Free Radic Biol Med,2015;89, 982-992.

80. Teeuw WJ, Slot DE, Susanto H, Gerdes VE,Abbas F, D'Aiuto F, Kastelein JJ, and Loos BG: Treatment of periodontitis improves the atherosclerotic profile: a systematic review and meta-analysis. J Clin Periodontol,2014;41, 70-79. 